\title{
Histopatologi dan Ekspresi TNF-a (Tumor Necrosis Factor- $\alpha$ ) Terhadap Kerusakan Hati akibat Invasi Parasit pada Ikan Kembung (Rastrelliger brachysoma)
}

\author{
Histopathology and TNF- $\alpha$ (Tumor Necrosis Factor- $\alpha$ ) Expression Against Liver \\ Damage due to Parasite Invasion in Mackerel (Rastrelliger brachysoma)
}

\author{
Allyes Amarens P. Lekatompessy ${ }^{1 *}$, Shelly M. Pattipeiluhu ${ }^{2}$, Bethsy J. \\ Pattiasina $^{2}$
${ }^{1}$ Mahasiswa Program Studi Magister Ilmu Kelautan, Pascasarjana Universitas Pattimura, Maluku Ambon, 97114, Indonesia
${ }^{2}$ Jurusan Budidaya Perairan Fakultas Perikanan dan Ilmu Kelautan, Universitas Pattimura Ambon, 97233, Indonesia
*Korespondensi: lekatompessyallyes45@gmail.com

\begin{abstract}
ABSTRAK
Ikan kembung (Rastrelliger brachysoma) merupakan salah satu jenis ikan pelagis kecil yang hidup di pesisir dan lepas pantai yang sering terinfeksi parasit. Penelitian ini bertujuan untuk mengidentifikasi endoparasit pada ikan dan pengaruh invasi pada jaringan hati ikan melalui teknik imunohistokimia. Hasil penelitian menunjukkan bahwa terdapat parasit yang menyerang hati ikan, antara lain Contracaecum sp dan Henneguya sp. Gambaran histopatologi jaringan hati menunjukkan beberapa infiltrasi sel, degenerasi sel dan nekrosis. Ekspresi TNF- $\alpha$ yang positif hampir semua jaringan hati ikan terinfeksi dan menyebabkan kerusakan pada ikan secara spesifik.
\end{abstract}

Kata kunci: endoparasit; histopatologi; ekspresi TNF- $\alpha$; imunohistokimia; hati

\begin{abstract}
Mackerel (Rastrelliger brachysoma) is a type of small pelagic fish lives on the coast and offshore that common infected by parasites. This study aims to identify endoparasits in fish and the effect of the invasion on fish liver tissue through immunohistochemistry technique. The results indicate that there were parasitic agents attack fish livers, including Contracaecum sp and Henneguya sp. The histopathology of liver tissue shows some cells infiltration, cells degeneration and necrosis. The TNF- $\alpha$ expression were positive that was almost all tissue of fish liver infected and cause damage to fish specifically.
\end{abstract}

Keywords: endoparasit, histopathology, TNF- $\alpha$ expression, immunohistochemistry, liver

\section{PENDAHULUAN}

Ikan kembung adalah salah satu jenis ikan pelagis kecil yang dapat ditemukan di pesisir pantai maupun lepas pantai dengan kedalaman 10-50 meter. Ikan ini dapat ukuran panjang mencapai $100 \mathrm{~cm}$ dan penyebarannya sangat luas di bagian tengah Indo-Pasifik (Peristiwady,
2006). Ikan kembung mudah didapat dan banyak dikonsumsikan oleh masyarakat karena memiliki kandungan protein yang tinggi dan rendah lemak (Yulvizar, 2013). Setiap perairan memiliki karakteristik fisik kimiawi yang berbedabeda sehingga dapat mempengaruhi respon sumber daya perairan terhadap 
kondisi penyebaran ikan. Salah satunya yang menjadi indikator aspek biologi terhadap ikan yaitu parasit (Williams dkk, 1992). Parasit adalah organisme yang hidup pada organisme lain dan memperoleh keuntungan dengan cara melakukan simbiosis serta membawa dampak negatif baik secara langsung maupun tidak langsung terhadap inang. Parasit banyak terdapat pada ikan dan beberapa diantaranya bersifat patogen bagi manusia. Diba dan Rahman (2018) menjelaskan bahwa ikan yang terinfeksi parasit tidak menyebabkan kematian tetapi pertumbuhannya terhambat, fekunditas inang menurun dan menyebabkan kerusakan pada jaringan organ tubuh inang. Rastrelliger

brachysoma merupakan salah satu ikan yang telah dilaporkan terkena parasit seperti Nematoda, Capilarrid, Branchiura dan Nerocila (Diba dan Rahman, 2018). Pemeriksaan inang secara histopatologi dan menggunakan metode imunohistokimia merupakan salah satu cara untuk mendukung diagnosis secara spesifik terhadap suatu penyakit. Infeksi parasit tidak menunjukan adanya gejala klinis sehingga harus dilakukan pembedahan dan pengamatan terhadap organ yang ditargetkan. Selain itu menurut Andriyanto, dkk., (2009) metode imunohistokimia memiliki sensitifitas yang tinggi dan cepat sehingga mampu mendeteksi antigen pada jaringan yang diperiksa dengan menggunakan antibodi yang spesifik sehingga terjadi ikatan antara antigen-antibodi kemudian dapat diamati menggunakan mikroskop.

Baratawidjaja (2014) menjelaskan bahwa TNF- $\alpha$ adalah protein yang dihasilkan oleh leukosit dalam merangsang dang mengaktifkan system imun terhadap respon inflamasi, yang patogen dalam keadaan normal akan memicu reaksi system imun secara spesifik maupun nonspesifik.

Penelitian ini bertujuan untuk mengetahui kerusakan jaringan hati ikan Rastrelliger brachysoma yang terinvansi endoparasit dan ekspresi TNF- $\alpha$ terhadap kerusakan jaringan.

\section{METODE PENELITIAN}

\section{Bahan}

Bahan-bahan yang digunakan dalam penelitian ini antara lain: sampel ikan kembung sebanyak 24 ekor, larutan $\mathrm{NaCl}$, formalin, xylol, alkohol bertingkat (75\%, 85\% dan absolut), hematoxilin euosin dan diaminobenzidine untuk pewarnaan imunohistokimia.

\begin{abstract}
Alat
Alat-alat yang digunakan dalam penelitian ini antara lain: pisau bedah, gunting, mikroskop elektron, timbangan digital analitik, cawan petri, kertas, label, slade kosong, cover glass dan tissue, dan zymed invitrogen kit Cat 95-9643.
\end{abstract}

\section{Metode Histopatologi dan Imunohisto- kimia}

Organ hati diambil dan dibersihkan dari darah yang menempel, kemudian difiksasi dengan formalin $10 \%$ selama 24 jam. Proses dehidrasi menggunakan alkohol bertingkat $(70 \%, 80 \%, 90 \%)$ dan alkohol absolut yang bertujuan menghilangkan kadar air dalam jaringan. Semua organ yang sudah difiksasi kemudian diproses untuk pembuatan histopatologi dengan menggunakan prosedur pewarnaan imunohistokimia. Proses pengerjaan pewarnaan imunohistokimia diantaranya deparafinisasi, digesti proteolitik, staining protocol, countertain dan mounting. Total ikan 24 ekor diambil 3 slide untuk pewarnaan hematoxilin euosin dan 3 slide untuk pewarnaan imunohistokimia dengan menggunakan antibodi.

Preparasi slide menggunakan cara Andriyanto (2009), untuk uji imunohistokimia mulai dari deparafinisasi sampai redehidrasi. Jaringan organ preparat histologi direaksikan dengan antibodi primer selama 30-60 menit. Apabila reaksi positif maka akan ditunjukan dengan warna coklat pada jaringan dengan sistem komplek imunohistokimia yang berasal dari Kit Zymed Invitrogen. 
Semua prosedur dari imunohistokimia dilakukan sesuai dengan petunjuk dari kit zymed invitrogen yang dipergunakan. Preparat yang telah diwarnai dengan hematoxilin eosin dijadikan counter stain. Setelah preparat sudah melalui proses dehidrasi hingga penjernihan maka preparat siap diamati dibawah mikroskop.

\section{HASIL DAN PEMBAHASAN}

Sebagian besar parasit memerlukan inang sebagai habitat sekaligus melengkapi siklus hidupnya. Ikan menjadi salah satu habitat dari berbagai jenis parasit, yang menyebabkan gangguan kesehatan dan kematian ikan. Banyak jenis parasit yang tidak menyebabkan kematian terhadap ikan namun tampilan ikan jelas terlihat ada perubahan (Hilal, 2016). Dalam penelitian ini ditemukan dua jenis endoparasit Contracaecum sp dan Henneguya sp yang hidup organ usus.

\section{Contracaecum sp}

Parasit ini (Gambar 1) termasuk dalam salah satu anisakiasis yang menginfeksi ikan. Larva parasit ini biasanya terdapat dalam rongga tubuh dan metasenterium. Terjadi pengikisan pada mukosa dan tingkat keparahannya tergantung dari jumlah cacing yang menyerang organ pada inang. Cacing akan membuat lubang pada mukosa di dalam organ inang. Nurcahyo (2014) menjelaskan bahwa Contracaecum spiculigerum adalah salah satu parasit yang juga ditemukan pada bebek, angsa dan jenis burung lain yang hidup disekitar perairan. Cacing jantan berukuran $32-45 \mathrm{~mm}$ dan cacing betina berukuran 24-64 mm. Biasanya dalam siklus hidup cacing ini, telur akan dilepaskan ke perairan melalui kotoran burung dan akan berkembang menjdai larva kemudian menginfeksi Copepoda cyclopoid, dimakan oleh ikan maka larva yang ada di dalamnya berkembang biak dan kemungkinan akan menempel pada organ inang. Inang yang terinfeksi cacing tersebut akan menjadi habitat bagi cacing tersebut dan siklus hidupnya lengkap.

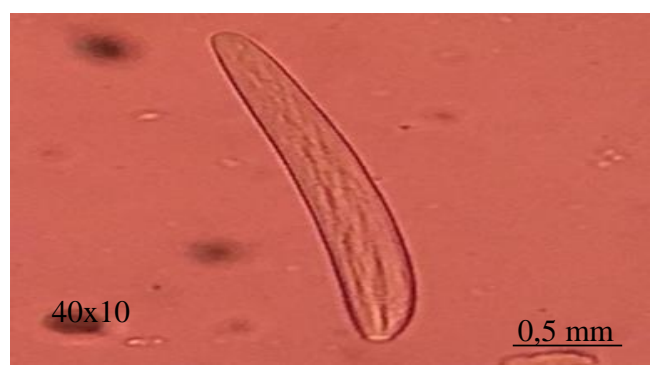

Gambar 1. Contracaecum sp

\section{Henneguya sp}

Henneguya sp (Gambar 2) merupakan parasit yang bentuknya langsing, fusiform, anterior sporanya berbentuk tumpul dan akan membesar pada bagian posterior. Ukuran panjang parasit ini berkisaran dari 10,6-12,6 $\mu \mathrm{m}$, lebar parasit 2,8-3,9 $\mu \mathrm{m}$ dan ketebalan mencapai $3,4 \mu \mathrm{m}$. Siklus hidup dari parasit ini diduga secara aseksual dan seksual. Stadium infeksi dari parasit ini berupa spora yang berfungsi sebagai alat untuk menyebarkan parasit. Setelah inang mati maka parasit akan keluar dari tubuh inang dan menginfeksi ikan yang lainnya. Spora akan menulari inang lainnya dengan menggunakan mekanisme transmisi. Spora akan tumbuh menjadi kista dan menghasilkan ribuan spora di dalam tubuh inang. Menurut Nurcahyo (2014), parasit ini merupakan organisme dari bivalvulida jenis protozoa yang tergolong dalam: Filum: myxozoa, Kelas: myxosporea, Ordo: bivalvulida, Sub Ordo: Platysporina, Family: Mxyobolidae, Genus: Henneguya

Pada dasarnya infeksi parasit terhadap organ ikan menimbulkan kerugian. Scholz (1999) menjelaskan bahwa infeksi menjadi salah satu faktor predisposisi terhadap infeksi yang lebih berbahaya dari patogen. Menurut Hartono. dkk (2021), ikan yang mengalami serangan penyakit disebabkan karena adanya interaksi antara inang, patogen dan lingkungan. 


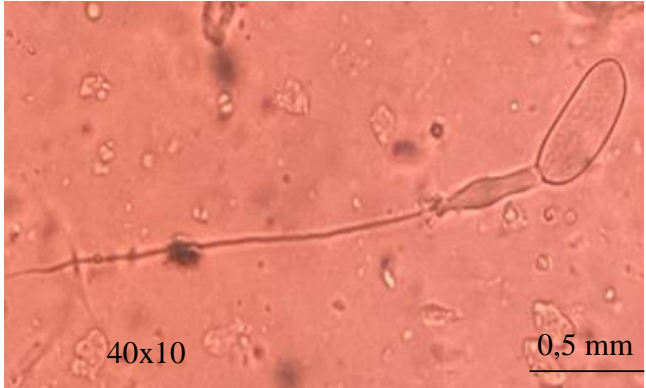

Gambar 2. Henneguya sp

Degenerasi sel ditandai dengan adanya inti sel yang mulai mengecil, warnanya lebih pekat dan pada sitoplasma terdapat vakuola yang di dalamnya berisi lemak. Degenerasi terjadi akibat adanya lemak yang tidak dikeluarkan dari sel. Penumpukan lemak terjadi karena sel mengalami defisiensi oksigen dan zat makanan sehingga mengganggu proses terbentuknya energi dan sel tidak mampu membentuk protein. Menurut Sari, dkk (2016) degenerasi sel dapat dilihat secara mikroskopis, ada vakuola yang berisi lemak di dalam sitoplasma hati, sesuai dengan hasil penelitian ini (Gambar 3).

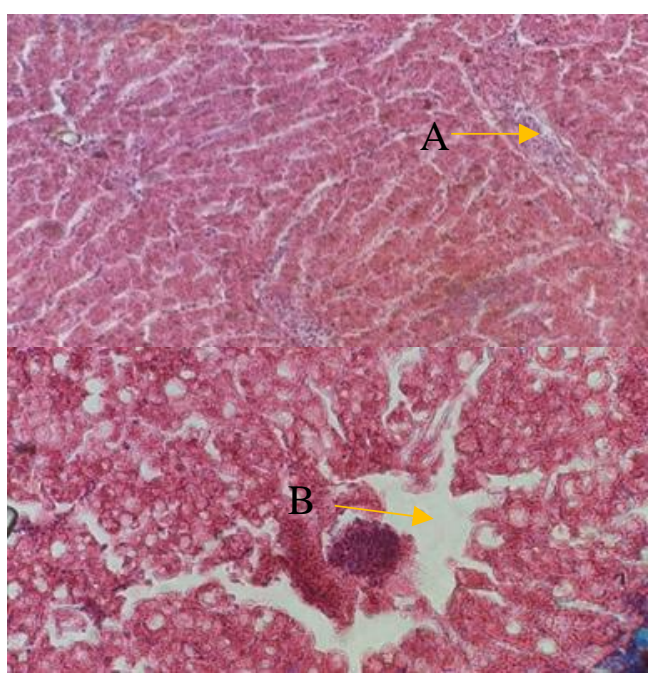

Gambar 3. Degenerasi sel (A), Nekrosis (B)

Nekrosis merupakan tahap lanjutan dari degenerasi sel yang ditandai dengan adanya struktur jaringan yang hilang dan daerah nekrosisnya mengalami bintik pendarahan. Dengan adanya nekrosis maka terjadi peradangan pada jaringan yang masih hidup. Peradangan ditandai dengan jendolan-jendolan darah dan jaringan yang berwarna merah disebabkan karena eritrosit keluar dari pembuluh darah. Tujuan dari peradangan ini untuk memulihkan jaringan dan menekan agen penyebab nekrosis. Sel yang mengalami nekrosis tidak mampu diasorbsi oleh sel fagosit sehingga unsurunsur dalam sel mudah terlarut dan mengeluarkan enzim litik. Setyowati, dkk (2011) menjelaskan bahwa histopatologi hati ikan berbeda dengan mamalia disebabkan karena sinusoid yang menyebar berjumlah sedikit dan dibatasi oleh sel endotelial sehingga penyebarannya tidak terjadi secara merata.

Dasar dari uji imunohistokimia adalah menunjukan adanya antigen dalam suatu jaringan oleh antibodi yang spesifik. Ketika antibodi dan antigen mengalami pengikatan maka terjadi sebuah reaksi warna dari histokimia. Metode imunohistokimia menambahkan Diaminobenzidine (DAB) untuk memperlihatkan adanya ikatan tersebut. Jika reaksi TNF- $\alpha$ (Tumor Necrosis Factor- $\alpha$ ) positif dapat ditandai dengan adanya warna coklat pada jaringan histopatologi. Hasil pengamatan mikroskop terhadap jaringan histopatologi yang mengalami ekspresi TNF- $\alpha$ dapat dilihat pada Gambar 4.

Deteksi antigen parasit pada organ hati terlihat pada sel-sel makrofag. Gambaran mikroskopik hasil penelitian menunjukan bahwa reaksi yang spesifik terjadi dalam sel antara antibodi yang digunakan dengan antigen parasit. Dari penelitian ini membuktikan bahwa ekspresi TNF- $\alpha$ dengan menggunakan teknik imunohistokimia pada jaringan histopatologi hati hasilnya adalah positif, sehingga hampir semua jaringan hati ikan mengalami infeksi. Jadi semakin banyak warna coklat pada jaringan histopatologi hati berarti semakin meningkatnya infeksi parasit terhadap jaringan tersebut. 


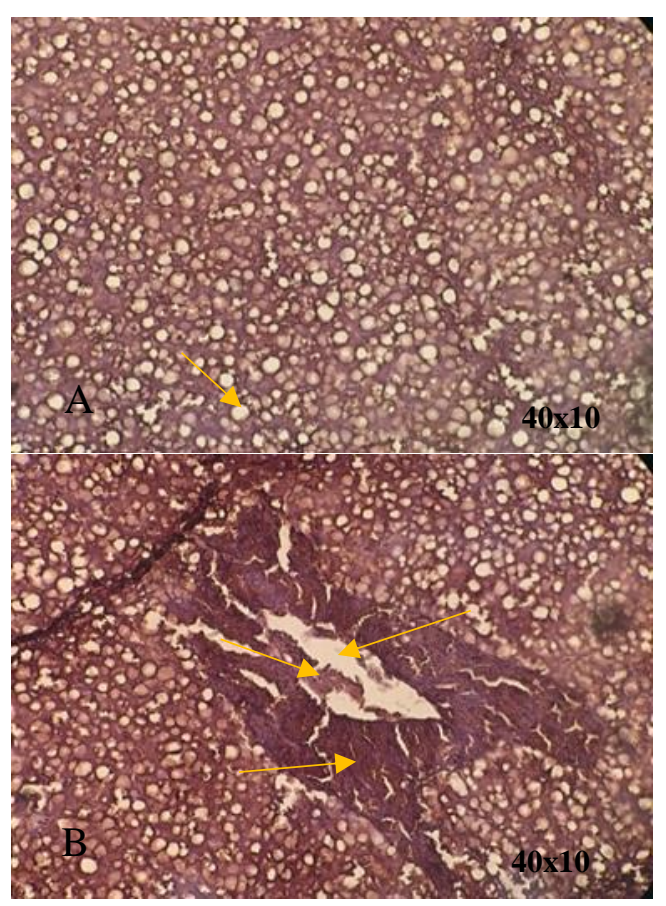

Gambar 4. Hati mengalami tiga kerusakan yaitu infiltrasi sel radang (A), vakuolisasi dan melanomakrofag (B). Perbesaran $40 \times 10$.

\begin{tabular}{ccc}
\hline $\begin{array}{c}\text { Organ } \\
\text { Target }\end{array}$ & $\begin{array}{c}\text { Histopato- } \\
\text { logi }\end{array}$ & $\begin{array}{c}\text { Reaksi } \\
\text { Imunohisto- } \\
\text { kimia }\end{array}$ \\
\cline { 2 - 3 } & Infiltrasi sel & Positif (+) \\
\cline { 2 - 3 } Hati & Degenerasi & Positif $(+)$ \\
\cline { 2 - 3 } & Nekrosis & Positif (+) \\
\hline
\end{tabular}

Dalam penelitian ini terlihat bahwa keadaan jaringan yang mengalami histopatologi dan dipengaruhi oleh ekspresi TNF- $\alpha$ adalah jaringan yang banyak mengalami beberapa gangguan misalnya infiltrasi sel radang, degenerasi sel dan nekrosis. Akibat gangguan kerusakan itu maka ekspresi TNF- $\alpha$ dapat berpengaruh terhadap jaringan yang rusak. Pewarnaan hematoxilin dan eosin juga berfokus pada sel yang mengalami peradangan berupa nekrosis sel-sel hepatosit yang ditandai dengan warna merah pekat. Sedangkan pewarnaan imunohistokimia berfokus pada reaksi antara antigen dan antibodi sehingga sel mengalami peradangan yang ditandai dengan warna coklat. Nasution dkk,
(2015) juga menjelaskan bahwa tidak ada perubahan patognomik secara histopatologi dengan penggunangan pewarnaan HE maka perlu dilakukan uji yang benar-benar menunjukan adanya agen parasit pada organ target dengan menggunakan teknik imunohistokimia. Dalam penelitian ini tidak dilakukan kuantifikasi kerusakan hati, baik pewarnaan HE dan IHK. Hal ini dapat dilakukan pada penelitian selanjutnya tingkat kerusakan hati akibat invasi parasit.

\section{KESIMPULAN}

Berdasarkan hasil penelitian maka dapat disimpulkan bahwa kehadiran parasit dapat dideteksi dengan menggunakan metode histopatologi dengan menggunakan teknik imunohistokimia yang dapat digunakan untuk mengetahui kerusakan jaringan hati ikan Rastrelliger brachysoma yang terinvasi endoparasit dan ekspresi TNF- $\alpha$ terhadap kerusakan jaringan.

\section{UCAPAN TERIMA KASIH}

Terima kasih kepada April Molle (Mahasiswa Magister Biologi, Universitas Brawijaya) dalam proses analisa sampel di laboratorium.

\section{DAFTAR PUSTAKA}

Andriyanto, S., Haririah., Yulianti, Y., Purnomo, S.H.I., Astuti, S. T., Nurlaila., Samudro, T., Priosoeryanto, B.P. (2009). Deteksi Edwardsiella tarda Secara Imunohistokimia Pada Ikan Patin (Pangasius pangasius).Fakultas

Kedokteran. Institut Pertanin Bogor. Jawa Barat.

Baratawidjaja , K. G. (2014). Imunologi Dasar: Sitokin. Balai Penerbit FK-UI. Jakarta.

Diba, D. W. dan Rahman, W. E. (2018). Gambaran Histopatologi Hati, Lambung Dan Usus Ikan (Katsuwonus 
pelamis) Yang Terinfeksi

Cacing Endoparasit.

Universitas Indonesia Timur, Makassar.

Hartono, P., Dewi, J.,Tusihadi, T. 2021. Penyakit Pada Budidaya Ikan Kerapu. Balai Budidaya Laut Lampung. Bandar Lampung.

Hilal. (2016). Parasitologi Ikan: Biologi, Identifikasi dan Pengendaliannya. Yogyakarta.

Nasution, S. S., Setiyono, A., Handharyani, E. (2015). Deteksi Imunohistokimia Antigen Coxiella burneti Sebagai Penyebab Q Fever Pada Sapi. Institut Pertanian Bogor. Bogor.

Nurcahyo, W. (2014). Parasit Pada Ikan. Universitas Gajah Mada. Yogyakarta.

Palm, H. W., Theisen, S,. Pikalov, E. Kleinertz.,S. (2018). Manipulation of Fish Phenotype by Parasits. Jurnal Elsevier. University of Rostock. Germany.

Peristiwady, T. (2006). Ikan-ikan Laut Ekonomis Penting di Indonesia. Petunjuk Identifikasi. LIPI Press Jakarta.

Sari, A. H. W. dan Perwira, I. M. (2019). Biomarker Histopatologi Hati Ikan Belanak (Mungil cephalus) Sebagai Peringatan Dini Toksisitas Kromium (Cr) Di Muara Tukad, Bali. Universitas Udayana. Bali.

Scholz, T. 1999. Parasites in Cultured and Feral Fish. Veterinary Parasitology 84, 317-335.

Setyowati, A., Hidayati, D., Awik., Abdulgani, N. (2011). Studi Histopatologi Hati Ikan Belanak (Mugil cephalus) Di
Muara Sungai Aloo Siduarjo.

Fakultas MIPA. Institut

Teknologi Sepuluh

November. Surabaya.

Williams, H.H., MacKenzie, K., McCarthy, A.M. (1992).

Prasites As Biological Indicators Of The Popilation Biology, Migrations, Diet, And Phylogenetics Of Fish. Rev. Fish. Biol. 2, 144-176

Yulvizar. (2013). Isolasi dan Identifikasi Probiotik Pada Rastrelliger sp. Universitas Syiah Kuala. Indonesia. 